\title{
In-vitro effectiveness test of leaf extract of cattapa and derris to control anthracnose in chili
}

\author{
Eli Korlina*, and Ahsol Hasyim \\ Indonesian Vegetable Research Institute, Jl. Tangkuban Perahu No. 517 Lembang, Bandung West \\ Java 40391 Indonesia
}

\begin{abstract}
Anthracnose disease (Colletotrichum capsici) is one of the main problem in the cultivation of chili. This study was aimed to discover about the extract of leaf extract of cattapa (Terminalia catappa $\mathrm{L}$ ) and leaf extract of derris (Derris elliptica) against the growth of Colletotrichum capsici causes anthracnosis in chilli. The study was conducted at the Mycology Laboratory of Institute Vegetables Research Indonesia, on July September 2018. The study used a randomized design complete (CRD) with nine treatments and three replications. The treatment consisted of: leaf extract of derris $(0.5 \% ; 1.0 \% ; 1.5 \% ; 2.0 \%)$, leaf extract of cattapa $(0.5 \%$; $1.0 \% ; 1.5 \% ; 2.0 \%$ ), and control (without treatment). The result showed that the leaf extract of derris more effective to suppress the conidial production of $C$. capsici . Development of colonies diameter leaf extract of derris was relatively smaller $(3.24-4.31 \mathrm{~cm})$, while for the treatment of leaf extract of cattapa showed larger colony size $(6.02-6.82 \mathrm{~cm})$.
\end{abstract}

\section{Introduction}

Anthracnose disease is a disease that caused by Colletotrichum capsici, besides being caused by $C$. acutatum and $C$. gloeosporioides. It is an important disease in several countries $[1,2,3]$, including Indonesia $[4,5]$ because every chili cultivation always gets anthracnose symptoms, especially when planting in the rainy season where the attack is relatively higher due to splashing water that spreads to healthy fruit [6]. The disease can attack leaves, flowers, twigs, and fruit [7]. However, the most frequent and very detrimental attack is on the fruit. Symptoms on chili peppers begin with small, round, slightly submerged spots and dark yellow spots turn brown and then black with irregular edges [8]. Damage caused by anthracnose attacks on chili can reduce chili production and quality up to $75 \%[9,10]$.

Several studies have been carried out in order to reduce the occurrence of anthracnose disease, one of them is assembling resistant chili varieties $[11,12,13]$. In addition, various controls were also tried, such as mechanically by taking diseased fruit and then burning it, biological control using Pseudomonas fluorescens [14], the use of Trichoderma harzianum [15] mixture with actinomycetes to suppress anthracnose more than $69 \%$ [16], and

* Corresponding author: korlinae@yahoo.co.id 
chemically [17]. The control of anthracnose disease is most often done by using a mixture of synthetic fungicides with high doses and relatively short spraying intervals (3-4 times a week). Unfortunately, it can cause environmental pollution and be harmful to the users themselves.

Alternative control using materials that are around the environment and safe for people is by utilizing plant materials as control agents. There have been many reports on the ability of botanical pesticides to suppress anthracnose disease, for example using garlic extract to suppress anthracnose disease in strawberry stolons by $83.7 \%$ [18]. Garlic extract is effective in controlling Phythopthora infestans effectively, both in vitro and in vivo [19].

Sambiloto, betel, and gambier have good potential in controlling C. gloeosporioides [20]. Some botanical pesticides potentially are used to control anthracnose, such as leaf extract of derris and catappa. The use of leaf extract of derris for pest control has been widely practiced. Hasyim et al. [21] has evaluated of leaf extract of derris on concentration and lethal time in onion caterpillar (Spodoptera exigua) in the laboratory. Meanwhile, leaf extract of derris for disease control have been tried against Fusarium oxysporum [22]. Leaf extract of cattapa (Terminalia catappa $\mathrm{L}$ ) is a member of the Combretaceae that is useful as an antibacterial because it contains tannin and flavonoid compounds [23]. This study aims to determine the effectiveness of leaf extract of derris and leaf extract of cattapa to control Colletotrichum capsici which causes anthracnose in chili peppers.

\section{Materials and methods}

The research was conducted at the Mycology Laboratory of Indonesian Vegetable Research Institute (IVEGRI) from July to September 2018. C. capsici isolate is a collection of IVEGRI Mycology laboratory obtained from symptomatic chilies from exploratory plantations in Sukabumi. The isolates were propagated in Potato Dextrase Agar (PDA) media as a source of inoculum to be tested. The pure isolate that was being used stay for seven days in PDA media. The pathogens were cultured by taking pure cultures of $C$. capsici that were already available with a $3 \mathrm{~mm}$ diameter cork borer, then planted in PDA media and incubated in an incubator at $28^{\circ} \mathrm{C}$ for seven days.

Leaves of derris and cattapa were cut and then ground using a mill to get uniform size of powder. The powder of each plant species was soaked in methanol $(1: 10 ; \mathrm{w} / \mathrm{v})$ for 72 hours. Each plant extract solution was filtered with filter paper (Whatman No.1) and methanol was evaporated using rotary evaporator at $50^{\circ} \mathrm{C}$ under reduced pressure $(400-450$ $\mathrm{mmHg})$ to produce crude extract. Crude extracts were kept under low temperature $\left(4^{0} \mathrm{C}\right)$ in the refrigerator until used. The extract solution of leaf extract of derris and leaf extract of cattapa was made with a concentration of $0.5 \% ; 1 \% ; 1.5 \%$, and $2 \%$ as well as controls (without treatment). All extracts are made in grams/volume $(\mathrm{g} / \mathrm{v})$. Production of $1 \%$ concentration solution of derris leaf extract was done by taking $1 \mathrm{~g}$ of leaf extract of derris paste then dissolving it in $99 \mathrm{ml}$ sterile distilled water, then stirring and filtering. The same process to make $1 \%$ concentration solution of cattapa leaf extract was to take $1 \mathrm{~g}$ of leaf extract of cattapa and then dissolve it in $99 \mathrm{ml}$ sterile distilled water.

C. capsici isolate used was isolated from chili plants infected with anthracnose disease in chili plantations in Ciamis, West Java in 2018. Before being poured into a petri dish, each leaf extract of derris and leaf extract of cattapa solution was filtered using sterilized Wattman filter paper. This was done to avoid contamination of both extract solutions. The antifungal test was carried out by pouring the filtered extract solution according to the concentration per treatment into a 1000 micrometer petri dish. Each concentration was repeated three times and each replication consisted of 3 petri dish. PDA media that has been diluted is added with antibiotics, then poured into a petri dish. Each of leaf extract of derris and leaf extract of cattapa was mixed with PDA media until evenly distributed. The PDA 
media which had been mixed with each extract was allowed to harden after which the pure pathogen of $C$. capsici was inoculated with a diameter of $3 \mathrm{~mm}$. The study was conducted using a completely randomized design. The parameters observed were the diameter of the colony growth of $C$. capsici growing on petri dishes and the inhibition percentage of each plant extract treatment.

\section{Results and discussion}

Antifungal activity of leaf extract of derris (Derris elliptica) and leaf extract of cattapa (Terminalia catappa L) on the growth of the pathogenic fungus Colletotrichum capsici at various concentrations are presented in Table 1 and Figure 1. Treatment of leaf extract of derris and leaf extract of cattapa with different concentrations showed different colony growth, especially between $1.5 \%$ concentration of leaf extract of cattapa 0.5 and $1 \%$ concentration of leaf extract of derris. On the second day of observation the colony growth of the two plant extracts, the result was not significantly different, except for leaf extract of derris and $1.5 \%$ concentration of leaf extract of cattapa which differed from $0.5 \%$ leaf extract of cattapa. Colony growth increased on the third day of observation, but all treatments showed an average colony that was almost evenly distributed and did not differ between treatments, ranging from 2.27 to $2.63 \mathrm{~cm}$.

On the fourth day of observation, the colony growth tended to be slow. Even in the leaf extract of derris the colony growth seemed to have stopped which was indicated by the absence of colony growth, while in leaf extract of cattapa treatment colonies continued to increase. Meanwhile for the control that was not given the two plant extract, the colony growth was seen to be higher fast.

On the fifth and sixth days of observation, there began to be a significant difference between the treatment of leaf extract of derris with a concentration of $0.5-2 \%$ with a $0.5-$ $5 \%$ leaf extract of cattapa ; 1 ; and $2 \%$, while $1.5 \%$ leaf extract of cattapa was not significantly different from $0.5 \%$ leaf extract of derris . In the seventh observation, it was very clear that the use of leaf extract of derris could slow the growth of $C$. capsici colonies which was significantly different from all concentrations of leaf extract of cattapa and controls. The difference in colony growth was due to the ability of antifungal activity of each plant extract. Leaf extract of derris was stronger in terms of suppressing the growth of pathogenic C. capsici than leaf extract of cattapa. According to Maini and Rejesus [24], leaf extract of derris contains active compounds, such as dequelin $(0.15-2.9 \%)$, eliptone $(0.35$ $4.6 \%)$ and toxicarol $(0-4.4 \%)$. While Hasyim et al. [21] found that from the results of GCMS analysis, leaf extract of derris contained 7-isopropensil-1, 4a dimethyl-4, 4a, 5,5,7,8hexahydro-3 H-naphthalen-2-0 ne, squalen2, ergosi-5-en-3-ol, compesterol stigmasterol, rotenone, gamma-sitosterol, 2,3,6-trimethoxy-5-methylphenol, and n-hexadeconoic acid. Based on these contents, it is possible that there are active ingredients that greatly affect the suppression of $C$. capsici pathogens. The same thing has been done to determine the antifungal potential in leaf extract of derris to suppress the pathogens Aspergilus flavus, $A$. fumigatus, C. albicans, P. notatum and Mucor sp [25]. According to Zahari et al. [26], Leaf extract of derris can also control $R$. microporus because it contains flavonoids and rotenoids. In this study, leaf extract of cattapa had not significantly inhibited the fungal pathogen $C$. capsici, whereas according to research by Babayi et al. [27], Leaf extract of cattapa (T. catappa) can suppress Candida albicans, Escheria coli [28] and Bacillus amyloliquefaciens [29] but both these microorganisms are bacteria, while in this study the target was fungi. 
Table 1. Development of Colletotrichum capsici colony diameter on leaf extract of derris and leaf extract of cattapa from different concentrations

\begin{tabular}{|c|c|c|c|c|c|c|c|c|}
\hline \multirow{2}{*}{ Treatments } & \multicolumn{7}{|c|}{ Colony diameter (cm) } & \multirow{2}{*}{$\begin{array}{c}\text { Avarage } \\
\text { (cm) }\end{array}$} \\
\hline & Day 1 & Day 2 & Day 3 & Day 4 & Day 5 & Day 6 & Day 7 & \\
\hline Derris leaf extract $0,5 \%$ & $\left.0,66 \mathrm{a}^{*}\right)$ & $1,60 a b c$ & $2,47 \mathrm{ab}$ & $2,47 \mathrm{a}$ & $3,78 \mathrm{ab}$ & $4,22 \mathrm{ab}$ & $4,31 \mathrm{a}$ & 2,79 \\
\hline Derris leaf extract $1,0 \%$ & $0,68 \mathrm{a}$ & $1,63 a b c$ & $2,49 a b$ & $2,49 \mathrm{a}$ & $3,15 \mathrm{a}$ & $3,38 \mathrm{a}$ & $3,50 \mathrm{a}$ & 2,12 \\
\hline Derris leaf extract $1,5 \%$ & $0,71 \mathrm{ab}$ & $1,51 \mathrm{a}$ & $2,55 \mathrm{ab}$ & $2,55 \mathrm{a}$ & $3,16 \mathrm{a}$ & $3,19 \mathrm{a}$ & $3,24 \mathrm{a}$ & 2,05 \\
\hline Derris leaf extract $2 \%$ & $0,69 a b$ & $1,55 \mathrm{ab}$ & $2,27 \mathrm{a}$ & $2,27 \mathrm{a}$ & $3,23 \mathrm{a}$ & $3,69 \mathrm{a}$ & $4,31 \mathrm{a}$ & 2,25 \\
\hline Catappa leaf ektract $0,5 \%$ & $0,75 \mathrm{ab}$ & $1,89 \mathrm{bc}$ & $2,65 \mathrm{~b}$ & $3,88 \mathrm{~b}$ & $4,99 \mathrm{~cd}$ & $5,63 \mathrm{c}$ & $6,62 \mathrm{~b}$ & 3,77 \\
\hline Catappa leaf ektract $1,0 \%$ & $0,65 \mathrm{a}$ & $1,72 a b c$ & $2,55 \mathrm{ab}$ & $3,94 \mathrm{~b}$ & $4,95 \mathrm{~cd}$ & $5,64 \mathrm{c}$ & $6,67 \mathrm{~b}$ & 3,73 \\
\hline Catappa leaf ektract $1,5 \%$ & $0,80 \mathrm{bc}$ & $1,52 \mathrm{a}$ & $2,63 \mathrm{~b}$ & $3,88 \mathrm{~b}$ & $4,29 \mathrm{bc}$ & $5,02 \mathrm{bc}$ & $6,02 \mathrm{~b}$ & 3,45 \\
\hline Catappa leaf ektract $2 \%$ & $0,90 \mathrm{c}$ & $1,65 a b c$ & $2,55 \mathrm{ab}$ & $2,75 \mathrm{a}$ & $4,95 \mathrm{~cd}$ & $5,70 \mathrm{c}$ & $6,59 \mathrm{~b}$ & 3,58 \\
\hline Control & 0,91 & $1,94 \mathrm{c}$ & $2,55 \mathrm{ab}$ & $4,00 \mathrm{~b}$ & $5,35 \mathrm{~d}$ & $5,02 \mathrm{bc}$ & $6,82 \mathrm{~b}$ & 3,79 \\
\hline CV (\%) & 7,56 & 10,85 & 6,67 & 9,18 & 11,85 & 14,11 & 15,03 & \\
\hline
\end{tabular}

${ }^{*}$ ) Mean score followed by the same letter are not significantly different at the $5 \%$ significance level according to Duncan's Multiple Range Test (DMRT)

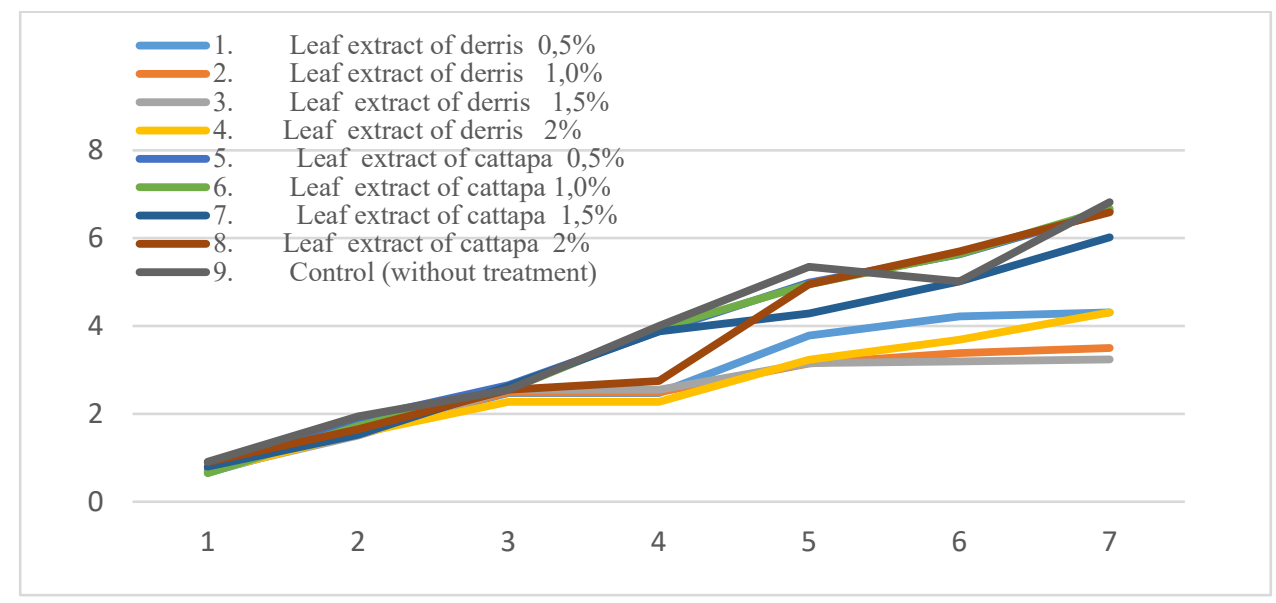

Fig. 1. Development of Colletotrichum capsici colony diameter on the media treated with leaf extract of derris and leaf extract of cattapa for seven days

Based on average the observation of colony growth from the age of 1 - 7 days after treatment, it appears that the colony growth of $C$. capsici isolates in the $1.5 \%$ Leaf extract of derris treatment showed the lowest colony area $(2.05 \mathrm{~cm})$. It was also followed successively with the same treatment on leaf extract of derris $1.0 \% ; 2 \%$ and $0.5 \%$ with an average of $2.12, ; 2.25$ and 2.79 respectively (Figure 2). Meanwhile, for the treatment of leaf extract of cattapa, C. capsici isolates were still growing from concentration $0.5 \%$ to $2 \%$ (3.45 - 3.77 $\mathrm{cm})$ which was almost similar with control (without treatment). 


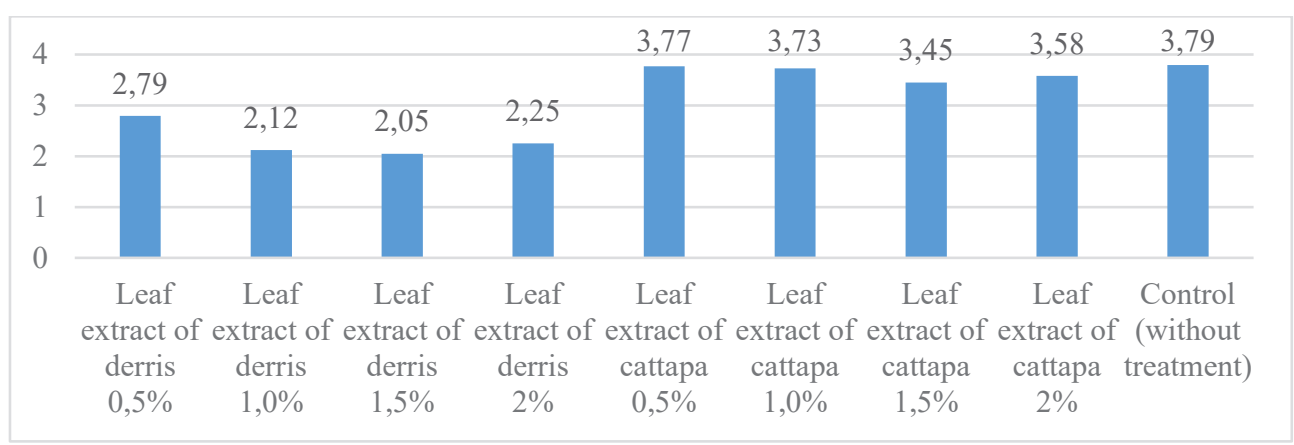

Fig. 2. Average colony diameter of Colletotrichum capsici on growth media treated with Derris leaf extract and Catappa leaf extract

Based on colony development, the level of suppression of each plant extract with different concentrations against the fungal pathogen C. capsici can be seen (Figure 3). From Figure 3, it can be explained that leaf extract of derris with a concentration of $0.5-2 \%$ has a high percentage of inhibition compared to leaf extract of cattapa. Meanwhile, of the four concentrations of leaf extract of derris, the highest percentage of inhibitory power resulted from a concentration of $1.5 \%$.

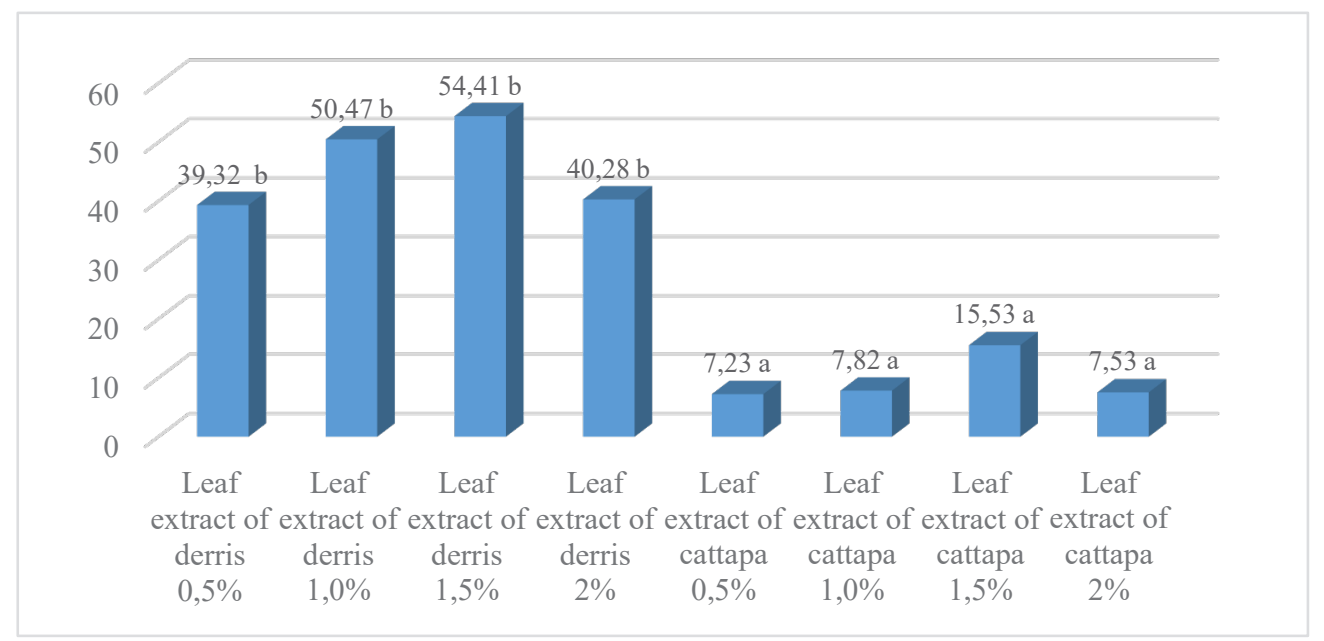

Fig. 3. Percentage of suppression of Derris leaf extract and Catappa leaf ektract against Colletotrichum capsici pathogens in vitro

\section{Conclusion}

Based on the test that had been conducted, the leaf extract of derris has a better potential to inhibit the growth hyphae of $C$. capsici instead of leaf extract of catappa. The leaf extract of derris at $1 \%$ and $1,5 \%$ concentration gave the highest inhibit each $50,47 \%$ and $54,42 \%$ respectively. The development of colony size at day seven for two treatments were $3,50 \mathrm{~cm}$ and 3,24 cm lower than the treatment of leaf extract of catappa $(6,02-6,67 \mathrm{~cm})$.

\section{References}

1. K.F. Alves, D. Laranjeira, M.P.S. Camara, C.A.G Camara, S.J. Michereff, Hortic. Bras. 33, 7 (2015) 
2. A. Narasimhan, S. Shivakumar, Biocontrol Sci. Technol. 25, 5 (2015)

3. J.K. Hong, H.J. Yang, H. Jung, D.J. Yoon, M.K. Sang, Y.C. Jeun, Plant Pathol. J. 31, 3, (2015)

4. I.D.M.P. Wiratama, I.P. Sudiarta, I.M. Sukewijaya, K. Sumiartha, M.S. Utama, EJurnal Agroekoteknologi Trop. Tropika 2, 2 (2013)

5. T.A. Soetiarso, W. Setiawati, J. Hort. 20, 3 (2010)

6. M.M. Oo, S.K. Oh, Korean Journal of Agric. Sci. 43,2 (2016)

7. P.S. Wharton, J.D. Uribeondo, An. del Jardín Botánico Madrid. 61, 1 (2004)

8. L. Soesanto, Kompendium penyakit-penyakit Cabai (Lily Publisher, 2019)

9. I.M. Hidayat, I. Sulastrini, Y. Kusandriani, A. H. Permadi, J. Hort. 14, 3 (2004)

10. M.R. Syukur, R. Yuniati, Dermawan, Budidaya Cabai Panen Setiap Hari (Penebar Swadaya, Jakarta, 2016)

11. S.H. Kim, J.B. Yoon, J.W. Do, H.G. Park, J. Crop. Sci. Biotech. 10, 5 (2007)

12. R. Kirana, Kusmana, A. Hasyim, R. Sutarya. J. Hort. 24, 3 (2014)

13. S.C. Ying, M.S. Li, Z.Z. Hai, P. Alain, W.L. Hao, Sci. Hortic. 181 (2015)

14. G. Pooja, G. S. Simon, J. Pharmacogn. Phytochem. 8, 1 (2019)

15. M.A. Rahman, M.M. Rahman, Md. Kamruzzaman, M.F. Begum, M.F. Alam, J. Bio \& Env. Sci. 2, 1 (2012)

16. L. Supriati, A.A. Djaya. J. Agri Peat. 16, 1 (2015)

17. A. Saxena, R. Raghuwanshi, V.K. Gupta, H.B. Singh, Front. Microbiol. 7 (2016)

18. N. Istifadah, A. Ayuningtyas, C. Nasahi. Agrologia. 6,1 (2017)

19. E. Ngadze, J. Biopes. 7, 2 (2014)

20. H. Idris, Nurmansyah, Bul. Littro. 26, 2 (2015)

21. A. Hasyim, W. Setiawati, L. Lukman, L.S. Marhaeni, J. Hort. 29, 1 (2019)

22. J.K.S. Jacob, E.S. David, J.R. Undan, J. Agric. Tech. 12, 1 (2016)

23. Y.L. Lin, Y.H. Kuo, M.S. Shiao, C.C. Chen, J.C. Ou, J. Chinese Chem. Soc. 47, 1 (2000)

24. P.N. Maini, B.M. Rejesus. Phillipine J. sience. 122, 1 (1993)

25. O.A. Mondal, K.A.M.S.H. Mondal, N. Islam, J. Life Earth Sci. 7 (2012)

26. R. Zahari, R. Halimoon, A.S. Sajap, M.F. Ahmad, M.R. Mohamed, J. Plant Sci. 2, 1 (2014)

27. H. Babayi, I. Kolo, J.I. Okogun, U.J.J. Ijah, Biokemistri. 16, 2 (2004)

28. R.C. Jagessar, R. Alleyne, Acad. Res. Int. 1, 3 (2011)

29. P.V. Tampemawa, J.J. Pelealu, F.E.F. Kandou, J. Ilm. Farm. 5, 1 (2016) 